Kees Waaldijk ${ }^{*}$

\title{
Free Movement of Same-Sex Partners
}

\section{$\S 1$. Homosexuality and Heterosexuality in Immigration Law}

National immigration law is restrictive. It limits the number of persons entitled to residence. Apart from nationals of the country itself, only limited categories of foreigners are entitled to residence. The restrictions contained in national immigration law use many criteria, including nationality, sex and marital status. In combination these criteria lead to various forms of discrimination of same-sex partners.

European law enlarges, to a certain degree, the number of persons entitled to residence. The right to respect for family life, ${ }^{1}$ for example, entails in certain circumstances a right for certain family members to live in the same country. The citizens of the Member States of the European Union have been given various rights to go and live in any other Member State, ${ }^{2}$ and to be accompanied by their spouses. ${ }^{3}$ In enlarging the number of people entitled to residence, both branches of European law have made use of the notion of marriage and related heterosexual concepts. So it remains to be seen whether European law can really improve the immigration rights of same-sex partners.

\section{$\S 2$. Free Movement of (Marital) Status}

Marriage is a queer sort of contract. It not only creates legal rights and duties between the two spouses, but also between them and children, creditors and other third parties. It is not only a matter of private law, but at least as much a public law institution: it can be decisive for the amounts of tax to be paid and for the level of social security pay-

Researcher, Human Rights Research School, Netherlands Institute of Human Rights SIM, University of Utrecht This article is based on a paper presented at the seminars Nouvelles formes de conjugalté enjeux polttques et légaux (organized by AIDES, Paris, 15 June 1996) and Obstacles to Freedom immigratton rights for same-sex couples within the European Union (organzed by Stonewall, London, 5 July 1996)

1 Article 8 of the European Convention on Human Rights

2 Articles 3, 8a, 48 and 52 of the European Community Treaty.

3 Artıcle 10 of EEC Regulation 1612/68, [1968] O J. L257/2 
ments, for acquiring residency, citizenship, etc.. It not only entails consequences provided by law, but also such advantages as private employers and service providers might add: better pension rights, free travel and other spousal benefits. Its consequences are not only material; marriage carries social and religious status too, not to mention its impact on the behaviour and identity of those involved.

And, to come to the point, marriage travels well. With only a few exceptions, a marriage concluded in one country is regarded as a marriage all over the world - with consequences inside and outside private and public law. One could say that there is a free movement of marital status, not infrequently assisting the free movement of married persons.

Although marriage may be universal and mobile, thus far it is a contract which can only be made between a woman and a man. However, a Dutch parliamentary resolution, ${ }^{4}$ and a court case in Hawaii have now raised a question of great practical interest: Would a marriage contracted between two people of the same sex be recognized abroad?

The relevance of a similar and related question is growing with the number of European countries that have enacted laws on registered partnership. Finland, the Netherlands, and other countries, seem set to follow the example of Denmark, Norway, Sweden, Greenland and Iceland. Will a registered partnership of two women or two men be recognized in other countries?

Both questions are related to a third, which has been of vital importance for a long time for the many lesbian and gay couples who live abroad together, or who would like to live in the same country, or who would like to move together to another country: Is their de facto relationship recognized internationally?

To these three factual questions a fourth, more normative question should be added: Does European law require the recognition of same-sex marriage, registered partnership, and/or unregistered same-sex relationships? By 'European law' I mean both European Union law and European human rights law.

\section{$\S 3$. To $\mathrm{R}$ or not to $\mathrm{R}$ ?}

To recognize or not to recognize, that seems to be the question. But in fact it is not.

This can be demonstrated with the example of registered partnership. Let us suppose for one moment that European law requires that registered partnerships be recognized throughout the European Union. Outside the countries that have introduced registered partnership, such recognition would not be of much help to any couple who are regis-

4. Kamerstukken II (Parlamentary Papers), 1995/96, 22700, nr. 18, adopted on 16 April 1996. 
tered partners. After all, the status of 'registered partner' does not have any consequences in the domestic law of other countries, nor in European Union law, nor in human rights law. Only in situations where domestic private international law refers to the law of a country that 'recognises' registered partnership, would the recognition of someone as 'registered partner' help that person (and then only if this would not be seen as incompatible with national public order). ${ }^{5}$ Such references, however, do not exist in any national immigration law.

Therefore, any questions about the transnational recognition of same-sex relationships need to be far more specific. In fact a whole matrix of questions need to be asked. Each question should be related to one of seven partnership concepts used in domestic and European law.

\section{§ 4. Seven Partnership Concepts in Law}

For the purposes of immigration a (married, registered or unregistered) partner might want to be included in one of these partnership concepts. If a foreigner wants to be allowed to live in the same country as his or her partner, he or she would hope to be recognized as:

a. being 'married' (in national immigration rules 'married' partners can normally qualify for a residence permit far more easily than unmarried partners); ${ }^{6}$

b. 'cohabitee' (living together can, for example according to paragraph B1/3.2 of the Dutch immigration rules, be a ground for a residence permit; however, in the Netherlands the additional conditions are a little stricter than those applicable to married partners; British immigration officers may use their discretion to admit cohabitees, although it has been reported that a 1985 instruction guiding their exercise of this discretion has been revoked);

c. 'registered partner' (in Denmark, Norway, Sweden, Greenland and Iceland registered partners have the same immigration rights as married partners, ${ }^{7}$ and in the

5. K. Boele-Woelkı and P.C. Tange, 'De Deense wet inzake het geregistreerd partnerschap. Een voorbeeld voor Nederland?', Nederlands Juristenblad (1989), 1543; Hans Ulrich Jessurun d'Oliveira, 'Geregistreerd partnerschap en de Europese Unie', Nederlands Juristenblad' (1995), 1570; K.McK. Norrie, 'Reproduction technology, transsexualism and homosexuality: new problems for international private law', 43 International and Comparattve Law Quarterly (1994), 757; Bea Verschraegen, Gleichgeschlechtliche 'Ehen', (Medien und Recht Verlags, 1994), 219-222; Lise Heide-Jørgensen, 'An Expansion of Fundamental Rights or an Erosion of Tradıtional Values? A Review Essay', 3 Maastricht Journal of European and Comparative Law (1996), 190-196.

6. See, for example, paragraph 281 of the UK Immigration Rules of 1994 [reproduced in M. Supperstone and D. O'Dempsey, Immigration: The Law and Practice, (Longman, 1994)] and paragraph B1/1.2 of the Dutch Immigration Rules, the Vreemdelingencirculaire of 1994.

7. Verschraegen, Gleichgeschlechtliche 'Ehen', 241-254. 
Netherlands they will have the same rights after the enactment of the registered partnership bill); ${ }^{8}$

d. 'spouse' (according to Article 10 (1) of EEC Regulation $1612 / 68,{ }^{9}$ the 'spouse' of any European Union citizen working in another Member State is entitled to residence in that country);

e. 'member of the family' (according to Article 10 (2) of Regulation 1612/68, Member States should 'facilitate the admission' of family members of workers who are not their spouse, child, grandchild, parent or grandparent, but only if they are dependent on the worker, or were living under the worker's roof in the original Member State);

f. having 'family life' with his or her partner (Article 8 of the European Convention on Human Rights requires family life to be respected);

g. having 'private life' with his or her partner (Article 8 of the Convention also requires respect for private life).

When combining these seven partnership concepts with the three types of same-sex relationships (unregistered, registered, married) we have in fact 21 questions:

Does European law require the recognition of:

I. unregistered same-sex partnership / partners

II. registered same-sex partnership / partners

III. same-sex marriage / married partners

as:
a. 'marriage'?
b. 'cohabitation'?
c. 'registered partnership'?
d. 'spouses'?
e. 'family'?
f. 'family life'?
g. 'private life'?

All these questions should not only be answered in the light of national laws and the European rules mentioned above, but also in the light of the various national and European manifestations of the principle of non-discrimination. More than one book would

8. See Kamerstukken II (Parlamentary Papers), 1993/94, 23761, nrs. 2 and 3.

9. [1968] O.J. L257/2. 
be needed to deal with all questions in depth, and more than one test case to settle them. Here I will briefly indicate some of the complications and possibilities.

\section{A. RECOGNITION AS 'MARRIAGE'}

The recognition of unregistered same-sex partners as being married may seem to be the least likely form of legal recognition. This is a mistake. As long as registered partnership is not introduced, and marriage is not open to same-sex couples, a forceful argument can be made for considering unregistered same-sex couples as 'married'. This argument has recently been embraced by a Dutch Court. ${ }^{10}$ It ruled that in certain circumstances same-sex cohabitees should be treated as if they were married. The case involved a man from Trinidad and Tobago who had been living together for some years with a Dutchman in the Netherlands. The man had been refused a residence permit, because his Dutch partner had insufficient income - in fact only a small social benefit, for he was unable to work because of AIDS. However, according to the Dutch immigration rules, ${ }^{11}$ such an income would have been considered sufficient as a basis for a residence permit, if the couple had been a married. Since they were not able to legally marry (and because of their notarial cohabitation contract in which they had made an effort to create similar rights and duties between each other as exist within marriage), the Court considered it discriminatory to apply the same conditions to them as are applicable to unmarried heterosexual couples.

The Court did not specify which manifestation of the principle of non-discrimination it used. It could have used Article 1 of the Dutch Constitution (the non-discrimination clause), or Article 429quater of the Dutch Penal Code, which makes it a criminal offence for anyone (including immigration officials) to discriminate (directly or indirectly) against homosexuals in the performance of a public office, a profession or a business. ${ }^{12}$ It also could have relied on the non-discrimination clause of the European Convention on Human Rights (Article 14). However, according to the (so far disappointing) case law of the European Commission of Human Rights, Article 14 allows for homosexual partners to be treated less favourably than heterosexual partners. The Commission has based this on the ground 'that the family (to which the relationship of heterosexual unmarried couples living together as husband and wife can be assimilated) merits special protection in society' and that it 'sees no reason why a High Contracting Party should not afford particular assistance to families'. ${ }^{13}$ Perhaps the line of argu-

10. President Rechtbank Den Haag (President of the Hague District Court); decision of 24 October 1995, Migrantenrecht (1996), nr. 4.

11. Paragraph B1/1.2, as opposed to paragraph B1/3.2 dealing with unmarried partners.

12. See Kees Waaldijk, 'The Legal Situation in the Member States', in Kees Waaldijk and Andrew Clapham (eds.), Homosexuality: a European Community Issue, (Martinus Nijhoff, 1993), 77-81, 114-115.

13. Simpson v. UK, No. 11716/85, 14 May 1986, D\&R 47, 274; cited in W.J. and D.P. V. UK, No. 12513/86, 13 July 1987, not reported in D\&R; in C. and L.M. v. UK, No. 14753/89, 9 October 1989, not reported in D\&R; and in B. v. UK, No. 16106/90, 10 February 1990, D\&R 64, 278; see 
ment of the Dutch Court may be used more successfully in future cases under the European Convention.

So far Dutch courts have not had a chance to recognize registered partnership. But I would think that the line of argument adopted by the Court in the case of the man from Trinidad, would also apply in the case of a same-sex partnership registered in one of the Nordic countries, and indeed in the case of a same-sex marriage contracted in, perhaps, Hawaii. My prediction would be that for the purposes of Dutch immigration law, foreign registered partnerships and same-sex marriages would be treated as 'marriages'.

\section{B. RECOGNITION AS 'COHABITATION'}

From a Dutch perspective it is always surprising to encounter legal rules which recognize cohabitation, but which limit that recognition to heterosexual cohabitation. ${ }^{14}$ For example, the instruction issued to British immigration officers on 8 November 1985 on the admission of cohabitees is limited to personal relationships outside marriage between members of the opposite sex. ${ }^{15}$

Here the distinction is not based on marital status, but directly on the sexual orientation of relationships (or in other words: on the sex of the partners involved). As I said, the European Commission of Human Rights so far accepts such a distinction. However, it has been pointed out that the validity of the Commission's argument depends on the assumption that homosexual couples are not 'family'. ${ }^{16}$ This may be criticized on the same grounds as the restrictive interpretation of 'family life' (see below, $\S 4$.F.). It has also been suggested, ${ }^{17}$ that the Commission's readiness to consider differential treatment of same-sex and different-sex couples as justified, is not in line with the requirement of 'very weighty reasons' in case of discrimination based on sex. ${ }^{18}$ In all samesex couple cases which have come before the Commission it could be argued that the applicants would have been treated more favourably if either partner had been of the other sex.

Therefore, in future cases it may be argued that the European Convention requires that same-sex cohabitation be recognized as 'cohabitation'.

$13 . \rightarrow$

Robert Wintemute, Sexual Orientation and Human Rights - The United States Constitution, the European Convention, and the Canadian Charter, (Clarendon, 1995), 123.

14. See Waaldijk, in Waaldijk and Clapham (eds.), Homosexuality: a European Community Issue, 93-101.

15. Supperstone and O'Dempsey, Immigration: The Law and Practice, 213. It has been reported that the 1985 instruction was recently revoked.

16. Pieter van Dijk, 'The Treatment of Homosexuals under the European Convention on Human Rights', in Waaldijk and Clapham (eds.), Homosexuality: a European Community Issue, 198.

17. Wintemute, Sexual Orientation and Human Rights, 126-129.

18. European Court of Human Rights, 28 May 1985, Abdulaziz, Series A, Volume 94, paragraph 78. 
Similar arguments may be developed to get registered partnership (or same-sex marriage) at least recognized as a form of cohabitation, in those countries that have not introduced registered partnership (or same-sex marriage).

\section{ReCognition as 'Registered Partnership'}

In 1995 Denmark, Norway and Sweden concluded a treaty obliging each of them to recognize partnerships registered in the other two countries. ${ }^{19}$ Later that year the Dutch State Secretary of Justice announced that, once the Dutch registered partnership law has been enacted, the possibility of acceding to that Nordic treaty would deserve consideration. ${ }^{20}$

It should be noted that there are some differences between the Nordic laws on registered partnership, and the Dutch proposal which is now before Parliament. One of these differences concerns the right to enter into a registered partnership. In the Nordic countries admission to registered partnership is regulated by a very strict condition, which has to be met by one of the partners (in Denmark, for example, at least one of the partners must be a Danish citizen residing in Denmark; similar requirements apply in the other Nordic countries). ${ }^{21}$ In the Dutch proposal, on the other hand, the conditions themselves are less strict, but they have to be met by both partners; each partner must have either:

- Dutch citizenship; or

a valid residence entitlement. ${ }^{22}$

It has been argued that the Nordic system is contrary to EU law, because it discriminates between EU citizens on the ground of nationality. Article 7 (2) of Regulation $1612 / 68{ }^{23}$ provides that citizens of another Member State must 'enjoy the same social and tax advantages as national workers'. In the Reed case the Court of Justice of the European Community held 'that the possibility for a migrant worker of obtaining permission for his unmarried companion to reside with him' is a 'social advantage for the purposes of Article 7 (2)'. ${ }^{24}$ Therefore the possibility of a migrant worker registering

19. Reported in the International Lesbian and Gay Association's ILGA Bulletin (1994, No. 3), 16.

20. Kamerstukken II (Parliamentary Papers), 1995/96, 22700, nr. 6, p. 23.

21. See Verschraegen, Gleichgeschlechtliche 'Ehen', 108, 121 and 129.

22. Kamerstukken II (Parliamentary Papers), 1995/96, 23761, nr. 9, proposed Article 80a of Book 1 of the Civil Code. In the original bill of 1994 an extra requirement was proposed for any partner(s) from outside the European Union. They would only be admitted to registered partnership after one years residence in the Netherlands. This requirement has been strongly criticised (see Jessurun d'Oliveira, Netherlands Juristenblad (1995), 1569), and has been dropped in the revised bill presented in the summer of 1996.

23. EEC Council Regulation 'on freedom of movement for workers within the Community', [1968] O.J. L257/2.

24. Case 59/85 Reed [1986] ECR 1303. 
a same-sex partnership in the same way as nationals can must also be considered a 'social advantage'. ${ }^{25}$

Since the requirement of a valid residence entitlement does not apply to foreigners who want to marry in the Netherlands, it can be argued that the Dutch system discriminates on the basis of sexual orientation, sex and civil status. ${ }^{26}$

It remains to be seen whether these restrictive conditions (aimed at preventing 'registration tourism' and/or 'registrations of convenience', i.e. the registration of 'fake-partnerships') will survive the various test cases which are bound to be brought.

An interesting point for discussion is, whether the immigration authorities in countries that have introduced registered partnership, should recognize unregistered partners of the same sex as 'registered partners', if these partners have no possibility to register their partnership in their home country.

Perhaps in countries that have introduced registered partnership themselves, married partners of the same sex will have to be recognized at least as 'registered partners' as long as the authorities are reluctant to recognize their marriage as 'marriage'.

\section{RECOGNITION AS 'SPOUSES'}

The strongest immigration rights for partners are those derived from European Union law. EU citizens who are exercising their EU right of freedom of movement have the right to be accompanied by their 'spouse'. For workers this is so because of Regulation 1612/68 (see above). A similar right exists for the spouses of self employed persons, service providers and receivers, retired persons, students, etc.. ${ }^{27}$

The Court of Justice of the EC has held that the term 'spouse' in Article 10 (1) of Regulation $1612 / 68$ 'refers to a marital relationship only'. ${ }^{28}$ Although this was decided in a case about a non-marital relationship between a Dutch man and an English woman, the outcome would probably have been the same in a case concerning a homosexual relationship.

25 Frank Emmert, 'The Famıly Polıcy of the European Communty', in Waaldık and Clapham (eds), Homosexuality a European Community Issue, 381-382, David O'Keeffe, 'Comments on the Free Movement of Various Categories of Persons', in H G Schermers et al (eds), Free movement of persons in Europe, (Martmus Nijhoff, 1993), 517.

26. See He1de Jørgensen, 3 Maastricht Journal of European and Comparattve Law (1996), 192, for detalls about a case in which the highest Danısh court ruled that the law on registered partnership cannot contain more restricted entrance conditions than those provided for marriage

27 See Hans Ulrich Jessurun d'Oliveira, 'Lesbians and Gays and the Freedom of Movement of Persons', In Waaldık and Clapham (eds.), Homosexualtty a European Community Issue, 297. 
However, it has been suggested that the time has come to reconsider Reed, and 'to find that - given the evolution in different Member States - the meaning of the term "spouse" has now (to be) broadened in order to encompass unmarried couples of whatever sex'. ${ }^{29}$ Apart from this 'sociological' argument in favour of including unmarried partners, a functional argument has been advanced which goes to the heart of EU law: Regulation 1612/68 is aimed at furthering the free movement of workers, and if a worker cannot be joined by his or her partner, his or her 'volition and ability to move within the Community will be seriously compromised". ${ }^{30}$ An extra argument could be based on equality as a fundamental principle of Community law (see $\S 4$.E., below). In its 'Resolution on equal rights for homosexuals and lesbians in the EC' the European Parliament has also demanded that 'the full rights and benefits of marriage' be made available to same-sex couples. ${ }^{31}$

It would be even easier for the Court of Justice to bring registered partners under the concept of 'spouse', than to include all unmarried partners in it. The similarities between married partners and (same-sex) registered partners are far greater than the similarities between married partners and (different-sex) cohabitees. Married partners as well as registered partners:

- $\quad$ are formally registered as such (which reduces the need to establish the existence of the relationship through factual evidence);

- have the same legal obligations regarding mutual maintenance etc. (with the exception of the legal relationships to children, but that is not relevant where the immigration of one of the partners is concerned); and

- $\quad$ need to go through a formal procedure before they can sever their ties (as opposed to cohabitees who can split up rather more easily).

In the Reed case it had been argued (by the Dutch Government!) that 'there is no reason (...) to give the term "spouse" an interpretation which goes beyond the legal implications of that term, which embrace rights and obligations which do not exist between unmarried companions'. ${ }^{32}$ In that light it can now indeed be claimed that registered partnership is 'a well-defined and officially registered partnership, which is in no way hampered by legal uncertainty' and therefore 'has to be considered as on an equal

29. Jessurun d'Olıverra, in Waaldık and Clapham (eds.), Homosexuality: a European Community Issue, 314. See also Heıde-Jørgensen, 3 Maastricht Journal of European and Comparative Law (1996), 185.

30. Andrew Clapham and J.H.H. Weiler, 'Lesbrans and Gay Men in the European Community Legal Order', in Waaldık and Clapham (eds.), Homosexuality: a European Community Issue, 42.

31 Resolution adopted on 8 February 1994, [1994] O.J. C61/40.

32. Case 59/85 Reed [1986] ECR 1302. 
footing with marital relationships, and the partners as "spouses" '. ${ }^{33}$ Accordingly registered partners would have the immigration rights conferred by Article 10 (1) of Regulation $1612 / 68$.

In the case of a same-sex marriage contracted in one Member State, all these arguments should not be necessary, although the Court could conceivably choose to restrict the meaning of the word 'spouse' to its traditional heterosexual notion. However, if it did that, the Court would be showing little respect for the national family law of that Member State. This would hardly be acceptable, because family law still is clearly within the domain of the Member States themselves. The only proper option for the Court of Justice would be to accept any marriage that is regarded as valid in at least one of the Member States - including a marriage between two women or two men.

\section{E. RECOGNITION AS 'FAMILY'}

As long as same-sex partners are excluded from the concept of 'spouse', they may be helped by the second paragraph of Article 10 of Regulation 1612/68. This provides that the Member States must at least 'facilitate the admission of any member of the family not falling within the provisions of paragraph 1 if dependent on the worker (...) or living under his roof in the country whence he comes'. Clapham and Weiler have argued that a same-sex partner should at least count as a 'member of the family' whose admission must be 'facilitated' by the Member States according to Article 10 (2). They not only base this on 'the human point of view' and the respect for private and family life required by Article 8 of the European Convention on Human Rights (see $\S 4 . F$ and $\S 4 . G$ below), but also on the functional argument (quoted in $\S 4 . \mathrm{D}$ above); they further argue that because Article 10 (2) is not concerned with spouses, parents and children, 'people outside the nuclear family are to be included'. ${ }^{34}$

I would be surprised if these arguments would not convince the Court of Justice, should a case arise in which an unregistered (or indeed registered or married) same-sex partner claims to be a family member for the purposes of Article 10 (2).

The problem with getting (unregistered, registered or married) same-sex partners recognized as 'members of the family' is that it does not produce a genuine right. It only triggers an obligation of the Member State to 'facilitate' admission.

However, the case law of the Court of Justice has repeatedly shown that in the field of Community law the Court does not allow national measures which are incompatible with

33. Jessurun d'Oliveira, in Waaldijk and Clapham (eds.), Homosexuality: a European Community Issue, 311.

34. Clapham and Weiler, in Waaldijk and Clapham (eds.), Homosexuality: a European Community Issue, 41-46. 
human rights and other general principles of Community law. ${ }^{35}$ The principle of equality is one of these fundamental principles. ${ }^{36}$

The willingness of the Court of Justice of the EC to give a generous interpretation to the principle of equality, has recently been demonstrated in a case of a transsexual claiming that his/her dismissal because of his/her planned sex-change amounted to sex discrimination. The Court agreed by considering that the principle of equal treatment for men and women does in fact mean that there should be no discrimination whatsoever on the grounds of sex, and that discrimination arising 'from the gender reassignment of the person concerned' is indeed 'based, essentially if not exclusively, on the sex of the person concerned'. ${ }^{37}$ In this case Advocate-General Tesauro spoke of the 'universal fundamental value, indelibly etched in modern legal traditions and in the constitutions of the more advanced countries: the irrelevance of a person's sex with regard to the rules regulating relations in society'. ${ }^{38}$ Any distinguishing between same-sex and different-sex couples would of course be based ('essentially if not exclusively') on the sex of the persons concerned. Therefore I think that the logic of the Court's judgment, and certainly that of the Advocate-General's opinion, suggests that in EU law any discrimination on the ground of sexual orientation will now count as a form of sex discrimination. It should be noted that the Human Rights Committee has reached the same conclusion as far as the International Covenant on Civil and Political Rights is concerned. ${ }^{39}$

The subject matter of Article 10 (2) of Regulation 1612/68 clearly falls within 'the field of Community law'. Therefore its application needs to be in conformity with the principle of equality. In the light of its judgment in Case C-13/94 P. v. S. and Cornwall County Council, ${ }^{40}$ it seems very unlikely that the Court of Justice would exclude equality between homosexual and (unmarried) heterosexual couples from this principle. So a forceful argument can be made, that in the area of Article 10 (2) the principles of Community law do not allow Member States to treat homosexual cohabitees (or registered partners) less favourably than heterosexual cohabitees. Whether the same argument will be equally forceful to end discrimination between cohabiting homosexuals and married heterosexuals, remains to be seen.

35. See for example Case C-260/89 ERT [1991] ECR 2963-2964.

36. Cases 117/76 and 16/77 Ruckdeschel [1977] ECR 1769.

37. Case C-13/94 P. v. S. and Cornwall County Council Judgment of 30 April 1996, paragraphs 17 and 20-21, not yet reported.

38. Paragraph 24 of his Opinion delivered on 14 December 1995.

39. See its Views in Toonen v. Australia, 31 March 1994, CCPR/C/50/D/488/1992, paragraph 8.7.

40. P. v. S. and Cornwall County Council Judgment of 30 April 1996, not yet reported, see above. 


\section{F. RECOGNITION AS 'FAMILY LIFE'}

Article 8 of the European Convention on Human Rights guarantees respect for 'family life'. The European Commission of Human Rights has repeatedly held that 'homosexual relationships' do not fall within the ambit of 'family life'. ${ }^{41}$ When it first used this interpretation in 1983, as well as when it last repeated it in 1992, the Commission said that this was so 'despite the modern evolution of attitudes towards homosexuality'. ${ }^{42}$ This at least suggests that a different interpretation would become possible in case of a further evolution of attitudes.

Van Dijk has rightly criticized the Commission for not having investigated in the later cases whether the evolution has already reached a point where the Commission should take a different stand. ${ }^{43}$ It should be noted that the attitudes towards same-sex partnership have been rapidly changing in many European countries over the last ten years. For example, the number of jurisdictions with anti-discrimination legislation explicitly covering sexual orientation has gone up from two to ten (Norway and France have been joined by Sweden, Denmark, Greenland, Ireland, the Netherlands, Spain, Finland and Slovenia). Progress in the field of same-sex partnership recognition has been made in many countries, including all Nordic countries, France, Spain, Hungary, Belgium and the Netherlands. ${ }^{44}$

There is also no basis for the restrictive interpretation in any of the judgments of the European Court of Human Rights, because the Court simply has not had an occasion to rule on this question, ${ }^{45}$ and because the Court (like the Commission) has given an 'otherwise very extensive, autonomous interpretation' to the concept of 'family life'. ${ }^{46}$ In contrast with the European Commission, the highest Dutch courts have already included same-sex relationships in their interpretation of 'family life'. ${ }^{47}$

Because of the criticism the decisions of the European Commission have generated, and because of the growing social and legal recognition of same-sex relationships in many European countries, a well-argued case might convince the Commission that it should

$X$ and $Y$ v UK, No 9369/81, 3 May 1983, D\&R 32, 220, Simpson $v U K$, No 11716/85, 14 May 1986, D\&R 47, 274, $C$ and $L M \vee U K$, No 14753/89, 9 October 1989, not reported in D\&R, Kerkhoven $v$ the Netherlands, No. 15666/89, 19 May 1992, not reported in D\&R $X$ and $Y$, Kerkhoven

43 Van Dijk, in Waaldık and Clapham (eds.), Homosexuality a European Community Issue, 190

44 See Kees Waaldık, 'Standard Sequences in the Legal Recognition of Homosexuality - Europe's Past, Present and Future', 4 Australasian Gay \& Lesbian Law Journal, (June 1994), 50, and see the monthly issues of the Euroletter published on behalf of the International Lesbian and Gay Association Wintemute, Sexual Orientation and Human Rights, 111

46 Van Dijk, in Waaldık and Clapham (eds ), Homosexualty a European Community Issue, 190

47 Hoge Raad (Supreme Court) 19 October 1990, Nederlandse Jurtsprudentte (1992), nr. 129; Afdeling Rechtspraak van de Raad van State (Judicial Division of the Council of State), 5 October 1993, Admintstratiefrechtelijke Beslissingen Kort (1993), nr 1117 
apply a more generous interpretation to the concept of 'family life'. The chances of getting registered partnership or same-sex marriage recognized as 'family life', are probably not much greater than the chances of getting unregistered same-sex cohabitation so recognized. After all, the Commission considers both married and unmarried heterosexual relationships as forms of 'family life'. ${ }^{48}$

So far the European Court of Human Rights has been prevented from ruling on the matter, because the Commission has declared inadmissible all applications about the position of same-sex couples. If the Commission keeps following this line, there will be a major chance of a breakthrough when the present Commission and Court are replaced by a new permanent European Court of Human Rights (as provided by Protocol No. 11 to the European Convention on Human Rights, which could come into force within a few years).

\section{G. Recognition as 'Private LiFE'}

Different aspects of homosexuality have been recognized in Strasbourg case law as being part of 'private life'. The European Court of Human Rights has ruled that sexual contact between two people of the same sex is 'a most intimate aspect of private life'. ${ }^{49}$ The European Commission of Human Rights also considers 'affirming and assuming one's sexual identity' as an aspect of 'private life'. ${ }^{50}$ Therefore, not surprisingly, the Commission has found in all its six cases about same-sex couples that their relationship constitutes 'private life' too. ${ }^{51}$

All these cases involved unregistered couples. It could be taken for granted that registered and married same-sex couples would also be seen as forms of 'private life'. However, this quite general recognition of same-sex relationships as 'private life' does not mean much in the field of immigration so far.

Firstly, in none of the cases has the Commission found an 'interference' with private life. ${ }^{52}$ All four immigration cases were about the deportation of the foreign partner of a British citizen. In the first case the Commission stated that because both partners were 'professionally mobile' it had not been shown 'that the applicants could not live together elsewhere than the United Kingdom, or that their link with the United Kingdom is an essential element of the relationship'. ${ }^{53}$ In the cases of W.J. and D.P. v. UK ${ }^{54}$

48. See Van Dijk, in Waaldijk and Clapham (eds.), Homosexuality: a European Community Issue, 190.

49. 22 October 1981, Dudgeon, Series A, Volume 45, paragraph 52.

50. F. v. Switzerland, No. 11680/85, 1988, D\&R 55, 178.

51. Kerkhoven v. the Netherlands, No. 15666/89, 19 May 1992, not reported in D\&R; Simpson v. UK, No. 11716/85, 14 May 1986, D\&R 47,274; and the four immigration cases against the United Kingdom, see below.

52. See Wintemute, Sexual Orientation and Human Rights, 103-105.

53. $X$ and $Y v . U K$, No. 9369/81, 3 May 1983, D\&R 32, 220.

54. No. $12513 / 86,13$ July 1987 , not reported in D\&R. 
and of C. and L.M. v. UK ${ }^{55}$ the Commission ruled that the disruption of private life by deportation ('in principle') only amounts to an 'interference' when there are 'exceptional circumstances'. All this is in line with the ruling of the European Court of Human Rights in the Abdulaziz case, ${ }^{56}$ that Article 8 does not imply a general obligation on the Contracting states 'to accept the non-national spouses for settlement'. According to Van Dijk, however, the Commission has been neglecting 'the homosexual factor' in these cases: precisely because of the homosexual character of their relationship, it would have been very difficult for the couples involved to go and live somewhere else. ${ }^{57}$

In one immigration case only, ${ }^{58}$ the question arose whether the interference complained about was justified. ${ }^{59}$ This case was about the deportation of a gay man to Cyprus. The Commission found that the possibility of 'hostility and social ostracism because of his homosexuality' did not outweigh 'valid considerations relating to the proper enforcement of immigration controls'. (This further proves the Commission's neglect of 'the homosexual factor'.)

Secondly, the alternative approach of invoking Article 14 (non-discrimination) in conjunction with the right to private life of Article 8 , has so far not been fruitful with the Commission. As I said ( $\$ 4 . \mathrm{A}$ and $\S 4 . \mathrm{B}$, above), the Commission considers less favourable treatment of homosexual partners objectively and reasonably justified on the ground 'that the family merits special protection in society'. So even in the context of 'private life' (a label readily attached to homosexual partnership) the exclusion of samesex relationships from the notion of 'family life' exerts its influence. By denying homosexual couples the label of 'family life' the Commission also weakens the additional protection that Article 14 might afford in the ambit of 'private life'.

This state of affairs might in future be overcome by getting the Strasbourg bodies to extend the notion of 'family life' to same-sex relationship (see $\S 4$.F, above). One could also try to convince the Commission and the Court that in the ambit of 'private life' same-sex partners are being treated less favourably because of the sex of one of them, that therefore a 'very weighty reason' would be needed to justify this distinction, and that the protection of the (heterosexual) family no longer amounts to such a reason (see $\S 4$.B, above). As a third line of argument one could question the proportionality between the refusal of residence on the one hand, and the aims of protecting 'the family' (or of controlling immigration) on the other.

55. No. $14753 / 89,9$ October 1989 , not reported in D\&R.

56. 28 May 1985, Series A, Volume 94, paragraph 68.

57. Van Dijk, in Waaldijk and Clapham (eds.), Homosexuality: a European Community Issue, 191-192.

58. B. v. UK, No. 16106/90, 10 February 1990, D\&R 64, 278.

59. See Wintemute, Sexual Orientation and Human Rights, 105-110. 


\section{$\S 5$. Free Movement of Partnership Status}

Only being recognized (at European level) as having a 'private life', is not a great help for same-sex partners who want to live together in a particular European country. To have their partnership fully recognized in other countries, they would need to be included in the more public concepts of partnership, such as 'family', 'marriage', 'spouse', 'registration' or even 'cohabitation'. Strong arguments to support this inclusion can be based on human rights and European Union law support, as I have tried to demonstrate.

A lesbian or gay couple that wants to acquire immigration rights on the basis of their relationship, need a public partnership status, a partnership status that is fully recognized in public policy. Only such a public status will move across borders reasonably freely. Courts and other national and European law makers should make same-sex couples eligible for such statuses - in the same way as the law has always provided different-sex couples with 'marriage' and other notions of partnership that travel freely around the world. In test cases and other areas the law should be challenged to do so.

As a public status 'marriage' would be the most effective, because it is an important criterion in the national (immigration) law of all countries. However, to win that status through parliamentary politics or test cases may be the most difficult of all, because of its traditional, religious background. Registered partnership would be more easily acquired, but only through legislation. The statuses of 'cohabitation', 'spouse' and 'family' have the great advantage that they can be acquired through the courts, without first having to mobilize a parliamentary majority.

'Private life' is not enough for lesbians and gay men who have come out, publicly, who want to live together, publicly, and who want to move from one country to the other, publicly. 